\title{
Pengembankan Asesmen Berorientasi Kontekstual Untuk Meningkatkan Kemampuan Literasi Matematis Dan Numerasi Mahasiswa
}

\author{
Anis Farida Jamil ${ }^{1}$, Arif Hidayatul Khusna ${ }^{2 *}$ \\ ${ }^{12}$ Universitas Muhammadiyah Malang \\ email:khusna@umm.ac.id
}

\begin{abstract}
Development of Contextual Oriented Assessment to Improve Students' Mathematical Literacy and Numeracy Skills. In this era, literacy and numeracy skills are needed in everyday life. Literacy skills are the ability to be able to apply mathematical concepts in the context of life and can do mathematical reasoning to explain an event, while numeracy skills are the ability to analyze and use numbers and mathematical symbols in solving practical problems in the context of everyday life. The purpose of this research is to develop a contextual-oriented assessment to improve students' mathematical and numeracy literacy skills that are valid, practical, effective, and reliable. However, the assessment developed is limited to test development. This research is a research and development type by going through three stages. The three stages are the identification and problem study stage, the development stage, and the assessment stage. The results of the development of this test assessment show a validity score of $85 \%$ which means very valid, scores on the ease of use aspect $78.5 \%$ and linguistic aspect $97.8 \%$ which means the product is in the practical category, students experience an increase in the percentage of achievement of all literacy and numeracy indicators which means This test assessment is effective, and Cronbach's Alpha reliability score $r=0.79$ which means the test assessment items are reliable.
\end{abstract}

Keywords: Assessment, Contextual, Literacy, Numeracy

\begin{abstract}
Abstrak
Pada era saat ini, kemampuan literasi dan numerasi dibutuhkan dalam kehidupan sehari-hari. Kampuan literasi adalah kemampuan untuk dapat menerapkan konsep matematika dalam konteks kehidupan serta dapat melalukan penalaran matematis untuk menjelaskan suatu kejadian sedangkan kemampuan numerasi adalah kemampuan menganalisis dan menggunakan angka-angka (number) dan simbol matematika dalam menyelesaikan masalah praktis dalam konteks kehidupan sehari-hari. Tujuan penelitian ini adalah mengembangkan asesmen berorientasi kontekstual untuk meningkatkan kemampuan literasi matematis dan numerasi mahasiswa yang valid, praktis, efektif, dan reliabel. Namun, asesmen yang dikembangkan terbatas pada pengembangan tes. Penelitian ini berjenis research and development dengan melalui tiga tahapan. Ketiga tahapan tersebut yaitu tahap identifikasi dan kajian permasalahan, tahap pengembangan, dan tahap penilaian. Hasil pengembangan asesmen tes ini menunjukkan skor kevalidan yaitu $85 \%$ yang berarti sangat valid, skor pada aspek kemudahan penggunaan $78,5 \%$ dan aspek kebahasaan $97,8 \%$ yang berarti produk berkategori praktis, mahasiswa mengalami peningkatan persentase ketercapaian semua indikator literasi dan numerasi yang berarti asesmen tes ini efektif, dan skor realibilitas Alpha Cronbach $r=0,79$ yang berarti butir asesmen tes reliabel.
\end{abstract}

Kata Kunci: Asesmen, Kontekstual, Literasi, Numerasi

\section{PENDAHULUAN}

Matematika merupakan ilmu yang berkaitan dengan kehidupan manusia. Oleh karena itu, matematika diajarkan dari jenjang pendidikan anak usia dini sampai tingkat perguruan tinggi. Melalui matematika, seseorang dapat dibekali kemampuan berpikir logis, kritis, kreatif, sistematis, analitis, dan inovatif (Karim et al., 2019; Mardhiyana \& Jailani, 2017). Kemampuan-kemampuan tersebut diperlukan seseorang untuk menjalani dan menyelesaikan permasalahan pada kehidupan sehari-harinya. Kompetensi yang dihasilkan oleh pelajaran matematika tersebut juga diperlukan seseorang untuk menghadapi keadaan yang mengalami perubahan dengan sangat cepat, tidak dapat ditentukan, serta kompetitif. Hal tersebut sejalan dengan tujuan pembelajaran matematika ditingkat perguruan tinggi.

Salah satu tujuan pembelajaran matematika di perguruan tinggi adalah menghasilkan lulusan yang memiliki kompetensi kompetitif serta problem solver yang baik. Oleh karena itu, perhatian dan penanganan yang serius harus dilakukan dalam mengembangkan pembelajaran matematika. Seorang pendidik dalam hal ini dosen, untuk mengetahui kualitas 
pembelajaran matematika yang sudah dilakukannya maka dibutuhkan suatu metode penilaian. Penilaian pembelajaran matematika yang dimaksud adalah asesmen. Asesmen merupakan bagian yang sangat penting dan tidak dapat dipisahkan dari pembelajaran (Mardhiyana \& Jailani, 2017; Seto \& Bantas, 2020; Yudha, 2019). Asesmen adalah proses pengumpulan informasi tentang pencapaian belajar mahasiswa (Mardhiyana \& Jailani, 2017). Asesmen dapat mendukung dosen dalam menentukan kesulitankesulitan belajar yang muncul pada mahasiswa. Kasus kesulitan belajar matematika masih banyak dialami mahasiswa (Annur, 2020; Anugraheni, 2020; Dirgantoro, 2019; Yasin \& Netriwati, 2019). Melalui asesmen, dosen dapat mengetahui perkembangan kemampuan matematis mahasiswa. Pengumpulan informasi tentang pencapaian belajar mahasiswa tidak hanya berupa tes namun dapat juga dikumpulkan melalui obervasi dan laporan diri. Namun dalam penelitian ini, asesmen yang akan dikembangkan dibatasi pada tes saja. Beberapa kemampuan matematis yang penting dikuasai mahasiswa antara lain kemampuan literasi matematis dan numerasi.

Kemampuan literasi matematis mahasiswa adalah kemampuan mahasiswa untuk dapat menerapkan konsep matematika dalam konteks kehidupan serta dapat melalukan penalaran matematis untuk menjelaskan suatu kejadian (Mujib et al., 2020; Setiawan \& Dores, 2019). Literasi matematis dapat membantu mahasiswa untuk mengetahui peran matematika pada kehidupan dan membantu dalam mengambil keputusan dalam hidupnya (Mujib et al., 2020). Oleh karena itu, penting untuk mengetahui sejauh mana kemampuan literasi matematis mahasiswa. Analisis kemampuan literasi matematis mahasiswa telah banyak diteliti dan menunjukkan hasil bahwa masih banyak mahasiswa yang memiliki kemampuan literasi matematis yang rendah (Oktaviyanthi \& Agus, 2019; Sukmawati, 2018). Hal tersebut ditunjukkan dengan rendahnya kemampuan mahasiswa dalam menyelesaikan masalah matematika.

Tidak terpisah dari kemampuan literasi matematis, kemampuan numerasi matematis juga dibutuhkan oleh mahasiswa. Kemampuan numerasi matematis adalah kemampuan menganalisis dan menggunakan angka-angka (number) dan simbol matematika dalam menyelesaikan masalah praktis dalam konteks kehidupan sehari-hari (Hartatik, 2020). Penelitian juga menunjukkan bahwa kemampuan numerasi mahasiswa masih tergolong rendah (Ayuningtyas \& Sukriyah, 2020; Hartatik, 2020). Dalam mempelajari matematika, mahasiswa tidak dapat mengindar dari penggunaan angka dan simbol. Pembelajaran matematika akan bermakna jika mahasiswa dapat menggunakan angka dan simbol matematis tersebut untuk menyelesaikan masalah sehari-harinya. Dosen membutuhkan informasi sejauh mana kemampuan numerasi matematis mahasiswa sehingga dapat mengidentifikasi kualitas pembelajaran.

Berdasarkan penjelasan di atas, penelitian ini bertujuan untuk mengembangkan asesmen berorientasi kontekstual untuk meningkatkan kemampuan literasi matematis dan numerasi mahasiswa. Bersesuaian dengan tujuan meningkatkan kemampuan literasi dan numerasi mahasiswa yang identik dengan penyelesaian masalah pada kehidupan seharihari maka asesmen yang dikembangkan berorientasi pada masalah dikehidupan seharihari atau kontekstual. Asesmen ini diharapkan dapat berguna bagi dosen untuk mendapatkan informasi kemampuan literasi dan numerasi mahasiswa. Dengan informasi tersebut, peningkatan kemampuan literasi dan numerasi mahasiswa diharapkan dapat meningkat. Asesmen berorientasi kontekstual yang dikembangkan untuk meningkatkan literasi matematis dan numerasi mahasiswa pada penelitian ini berkategori valid, praktis, efektif, dan reliabel.

Peta jalan (road map) pada penelitian pengembangan asesmen berorientasi kontekstual untuk meningkatkan kemampuan literasi dan numerasi matematika mahasiswa digambarkan pada bagan berikut. 


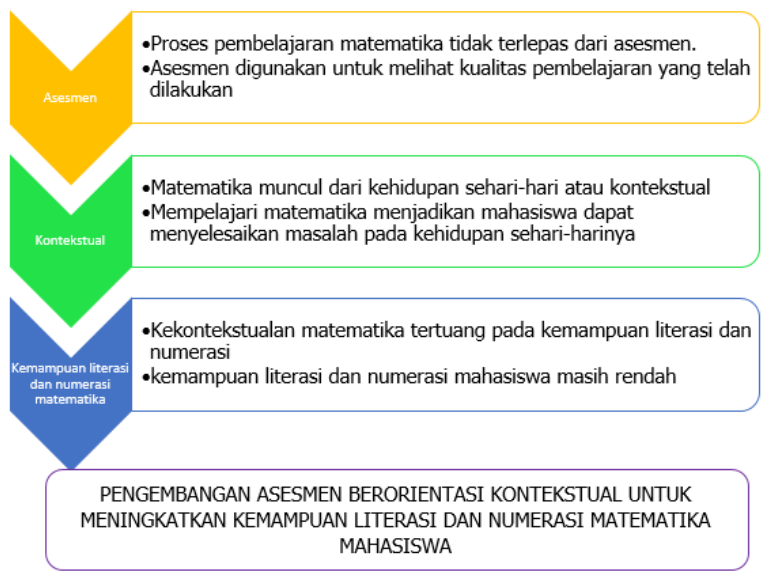

Asesmen merupakan suatu proses yang berisi data kualitatif maupun kuantitatif yang digunakan seorang pendidik untuk mendapatkan informasi dan menarik keputusan mengenai peserta didik, kurikulum, maupun pembelajaran (Muta'ali, 2020). Asesmen bertujuan untuk mengetahui kompetensi siswa sehingga memudahkan pendidik untuk melakukan umpan balik atau evaluasi guna memperbaiki kualitas pembelajarannya (Musthofa, 2019). Dalam pelaksanaannya, asesmen terbagi menjadi tiga istilah yaitu pengukuran, evaluasi, dan tes. Pengukuran diartikan sebagai kegiatan yang dilakukan dengan memberikan angka-angka pada suatu gejala atau peristiwa sehingga hasilnya memang berupa angka. Evaluasi adalah proses pemberian makna atau ketetapan kualitas pengukuran dengan cara membandingkan angka hasil pengukuran dengan kriteria tertentu sebagai pembanding. Sedangkan tes adalah seperangkat tugas yang harus dikerjakan dan dijawab oleh peserta didik untuk mengukur tingkat pemahaman dan penguasaannya pada suatu materi pembelajaran dan sesuai dengan tujuan pembelajaran.

Pada penelitian ini, asesmen yang akan dikembangkan adalah berupa tes. Tes dipilih karena penelitian ini bertujuan untuk meningkatkan kemampuan literasi dan numerasi matematika mahasiswa. Dengan pengembangan instrumen asesmen berupa tes, maka peneliti dapat mengetahui dan mengukur kemampuan literasi dan numerasi mahasiswa.

Literasi matematika merupakan kemampuan individu untuk memformulasikan, menggunakan, dan menafsirkan matematika dalam berbagai konteks kehidupan (Hidayat et al., 2019). Literasi matematika yang berkaitan dengan kemampuan menerapkan matematika kedalam masalah sehari-hari sehingga komponen penting dalam literasi matematika adalah penyelesaian masalah nyata. Proses penyelesaian masalah ini disebut dengan matematisasi. Tahapan proses metamatisasi antara lain merumuskan, menggunakan, menafsirkan, dan mengevaluasi. Berikut gambar yang menggambarkan proses matematisasi.

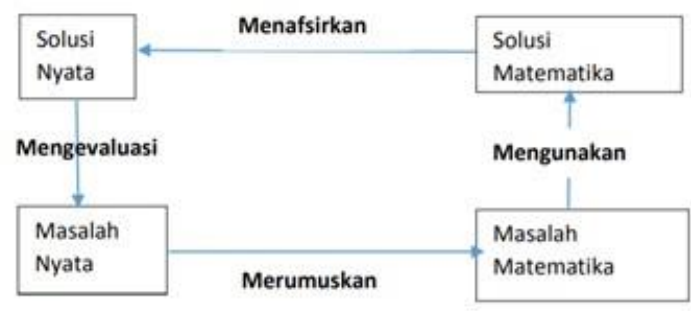

Sumber: (Hera \& Sari, 2015)

Berdasarkan proses matematisasi pada gambar di atas, berikut tabel penjelasan atau indikator literasi matematika.

Tabel 1. indikator literasi matematika

\begin{tabular}{llll}
\hline \multicolumn{3}{c}{ Literasi Matematika } & \\
\hline Proses Matematisasi & \multicolumn{2}{l}{ Indikator } & \\
\hline Merumuskan masalah nyata & $\bullet$ & Mengkonstruksi & \\
& & masalah & \\
& $\bullet$ & Menyederhanakan \\
& & masalah & \\
& $\bullet$ & Membuat r & model \\
& & matematika & dari \\
& & masalah & \\
& &
\end{tabular}

\begin{tabular}{cl}
\hline Menggunakan matematika & $\begin{array}{l}\text { Bekerja dengan } \\
\text { matematika }\end{array}$ \\
\hline Menafsirkan solusi & $\begin{array}{l}\bullet \\
\text { • Menafsirkan solusi }\end{array}$ \\
\hline Mengevaluasi solusi & Memyajikan solusi \\
\hline Kemampuan & numerasi matematika
\end{tabular}
merupakan kecakapan dalam menggunakan berbagai angka dan simbol matematika untuk memecahkan masalah pada kehidupan seharihari, serta kemampuan menganalisis informasi yang ditampilkan pada berbagai bentuk misalnya tabel, grafik, bagan, dan lain-lain (Hartatik, 2020). Numerasi mencakup keterampilan mengaplikasikan konsep dan kaidah matematika dalam situasi real sehari-hari, permasalahan yang diberikan sering kali tidak terstruktur, memiliki banyak cara penyelesaian atau bahkan tidak ada penyelesaian yang tuntas (Mahmud \& Pratiwi, 2019). Berikut tabel indikator dan penilaian kemampuan numerasi mahasiswa. 
Table 2. tabel indikator dan penilaian kemampuan numerasi mahasiswa

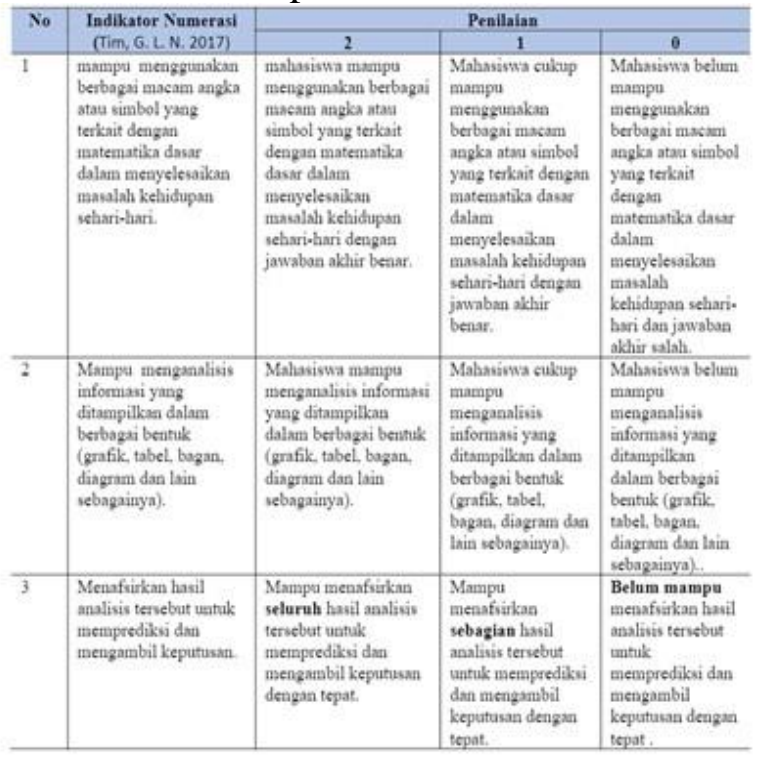

Sumber: (Hartatik, 2020)

Berdasarkan penjelasan di atas, penelitian ini bertujuan untuk mengembangkan asesmen berorientasi kontekstual untuk meningkatkan kemampuan literasi matematis dan numerasi mahasiswa. Bersesuaian dengan tujuan meningkatkan kemampuan literasi dan numerasi mahasiswa yang identik dengan penyelesaian masalah pada kehidupan seharihari maka asesmen yang dikembangkan berorientasi pada masalah dikehidupan seharihari atau kontekstual. Asesmen ini diharapkan dapat berguna bagi dosen untuk mendapatkan informasi kemampuan literasi dan numerasi mahasiswa.

\section{METODE}

Penelitian ini berjenis penelitian pengembangan (Research and Development). Tujuan penelitian ini adalah untuk menghasilkan produk berupa asesmen yang dapat meningkatkan kemampuan literasi matematis dan numerasi mahasiswa yang berkategori valid, praktif, efektif, dan reliabel. Asesmen yang dikembangkan dibatasi hanya pada pengembangan tes. Kegiatan yang dilakukan dalam proses pengembangan asesmen ini diawali dengan identifikasi dan kajian permasalahanpermasalahan yang terjadi mengenai kemampuan literasi matematis dan numerasi mahasiswa. Pada tahap ini selain identifikasi masalah, kajian terhadap literatur juga dilakukan dari artikel jurnal hasil penelitian-penelitian. Tahapan kedua adalah tahap pengembangan. Pada kegiatan ini dilaksanakan penyusunan kisikisi soal dan draft awal soal tes, maupun menyusun lembar validasi dan angket. Pada tahapan pengembangan ini pula dikembangkan soal tes yang dapat meningkatkan kemampuan literasi matematis dan numerasi mahasiswa. Tahapan terakhir adalah tahapan penilaian. Pada tahapan ini dilakukan penilaian formatif oleh para ahli untuk mengukur kevalidan tes selanjutnya uji coba produk. Uji coba produk dilakukan ketika asesmen yang dikembangkan masuk kategori minimal valid. Tahapan uji coba ini untuk mengetahui kevalidan dan reliabilitas asesmen.

Berdasarkan penjelasan di atas, instrumen yang digunakan pada penelitian ini adalah lembar validasi, lembar angket respon mahasiswa, dan hasil tes mahasiswa. Lembar validasi digunakan untuk mengukur kevalidan asesmen. Lembar angket respon mahasiswa untuk mengetahui kepraktisan asesmen, dan hasil tes mahasiswa untuk mengetahui keefektifan asesmen. Selain itu, hasil tes juga digunakan uji reliabilitas soal yaitu untuk menentukan tingkat konsistensi butir tes dalam mengukur kemampuan literasi matematis dan numerasi mahasiswa. Uji reliabilitas asesmen diukur menggunakan bantuan software SPSS sehingga diperoleh nilai koefisian reliabilitas Alpha Cronbach. Hasil Cronbach $\alpha$ mempunyai rentang antara 0 sampai 1 (Heale \& Twycross, 2015). Berikut tabel kriteria tingkat reliabilitas suatu tes.

Tabel 3. Kriteria Koefisien Hasil Reliabilitas

\begin{tabular}{lll}
\hline No. & $\begin{array}{l}\text { Tingkat } \\
\text { Reliabilitas }\end{array}$ & Kriteria \\
\hline 1. & $0,70 \leq \mathrm{r} \leq 1$ & Reliabel \\
2. & $0,50 \leq \mathrm{r}<0,70$ & Kurang reliabel \\
3. & $0 \leq \mathrm{r}<0,50$ & Tidak reliabel \\
\hline
\end{tabular}

Selanjutnya, data yang diperoleh dari hasil validasi diubah menjadi data kuantitaif dengan penskoran sebagai berikut.

Tabel 4. Kategori Skor Lembar Validasi

\begin{tabular}{clc}
\hline No. & \multicolumn{1}{c}{ Kategori } & Skor \\
\hline 1. & Sangat setuju (SS) & 4 \\
2. & Setuju (S) & 3 \\
3. & Tidak setuju (TS) & 2 \\
4. & Sangat tidak setuju (STS) & 1 \\
\hline
\end{tabular}


Kemudian dilakukan perhitungan berdasarkan rumus sebagai berikut (Prasetiyo \& Perwiraningtyas, 2017),

Keterangan :

$$
P=\frac{\sum x}{\sum x_{i}} X 100 \%
$$

$$
\begin{aligned}
& \mathrm{P}=\text { Persentase } \\
& \sum x=\text { Jumlah bobot skor yang diperoleh } \\
& \sum x_{i}=\text { Jumlah Keseluruhan bobot skor } \\
& 100=\text { Konstanta }
\end{aligned}
$$

Tabel 5. Kriteria Persentase Hasil Validasi

\begin{tabular}{clc}
\hline No. & Tingkat validitas $(\%)$ & kriteria \\
\hline 1. & $75<\mathrm{P} \leq 100$ & Sangat valid \\
2. & $50<\mathrm{P} \leq 75$ & Valid \\
3. & $25<\mathrm{P} \leq 50$ & Kurang valid \\
4. & $0 \leq \mathrm{P} \leq 25$ & Tidak valid \\
\hline
\end{tabular}

Data kepraktisan asesmen diperoleh dari hasil pengisian angket oleh mahasiswa. Asesmen yang dikembangkan dikatakan praktis ketika hasil angket respon mahasiswa masuk kategori respon positif. Keefektifan asesmen yang dikembangkan diperoleh dari hasil tes mahasiswa yang menunjukkan peningkatan kemampuan literasi dan numerasi mahasiswa.

\section{HASIL DAN PEMBAHASAN}

Sesuai dengan tujuan penelitian yaitu menghasilkan produk berupa asesmen yang dapat meningkatkan kemampuan literasi matematis dan numerasi mahasiswa yang berkategori valid, praktif, efektif, dan reliabel, tahapan penelitian terdiri dari (1) identifikasi dan kajian permasalahan-permasalahan, (2) tahap pengembangan, dan (3) tahapan penilaian.

\section{Tahapan Identifikasi dan Kajian Permasalahan}

Pada tahapan ini dilakukan identifikasi dan kajian permasalahan-permasalahan yang terjadi mengenai kemampuan literasi matematis dan numerasi mahasiswa. Berdasarkan hasil identifikasi masalah ditemukan bahwa perlunya dosen mengetahui perkembangan kemampuan matematis mahasiswa. Kemampuan matematis yang dimaksud dalam penelitian ini adalah kemampuan literasi dan numerasi. Selain itu berdasarkan hasil penelitian yang lain masih rendahnya kemapuan literasi dan numerasi khususnya bagi mahasiswa pendidikan matematika. Selain identifikasi masalah, kajian terhadap literatur juga dilakukan dari artikel jurnal hasil penelitian-penelitian. Tahapan ini menghasilkan penetapan indikator literasi dan numerasi yang akan digunakan untuk pedoman pembuatan asesmen.

\section{Tahapan Pengembangan}

Pada tahapan ini dilakukan perancangan produk asesmen yang dapat meningkatkan kemampuan literasi matematis dan numerasi mahasiswa serta instrument penelitian yaitu lembar validasi untuk menguji kevalidan produk dan angket untuk menguji kepraktisan produk. Produk asesmen didesain menggunakan prinsip kontekstual dan berkaitan dengan materi yang diajarkan yaitu benda kuadratis ruang sub bab bola dan hiperboloida. Produk asesmen terdiri dari tiga permasalahan kontekstual yang terdiri dari dua permasalahan bola dan satu permasalahan hiperboloida. Selain berorientasi kontekstual, penyusunan produk asesmen ini berpedoman pada indikator kemampuan literasi dan numerasi sehingga dapat digunakan untuk menilai peningkatan kemampuan literasi dan numerasi mahasiswa.

Penyusunan lembar validasi disesuaikan dengan tujuannya yaitu untuk menilai kevalidan produk dari segi prinsip kontekstual, kesesuaian indikator literasi dan numerasi, dan kebahasaan. Sedangkan angket menilai kepraktisan produk dari sisi kemudahan penggunaan dan kebahasaan.

\section{Tahapan penilaian}

Tahapan penilaian ini digunakan untuk melihat kualitas produk asesmen yang dikembangkan yaitu kevalidan, kepraktisan, keefektifan, dan reliabilitas produk asesmen yang telah dikembangkan. Berikut dipaparkan hasil masing-masing kriteria.

\section{Kevalidan Produk Asesmen Berorientasi Kontekstual}

Kevalidan produk dinilai oleh validator ahli yaitu seorang dosen yang memiliki kepakaran dibidang pendidikan matematika khususnya dibidang asesmen dan evaluasi. Kevalidan produk dinilai dari tiga aspek yaitu prinsip kontekstual, kesesuaian indikator literasi dan numerasi, dan kebahasaan. Pada aspek kontekstual, validator memberikan penilaian sangat baik, aspek literasi memberikan penilaian baik, aspek numerasi memberikan penilaian 
sangat baik dan aspek kebasaan juga mendapat predikat sangat baik. Sehingga secara keseluruhan produk asesmen yang dikembangkan bernilai sangat valid dengan persentase $85 \%$. Meskipun begitu ada sedikit revisi dari validator yaitu pada permasalahan nomor satu.

TUJUAN
Menilai kemampuan literasi
dan numaerasi maahasiswsa
MATERI
1. Bola

MASALAH 1

Seorang Astronot menemukan benda berbentuk bola yang terpantau dilayar radar. Untuk keperluan keamanan, astronot tersebut ingin engetahui volume dari benda tersebut. Berdasarkan pantauan radar, pusat benda tersebut berada dikoordinat $(1,1,4)$ dan benda tersebut menxinggung bidang $x+y=12$. Bantulah agar Astronot tersebut

Gambar 1. Permasalahan sebelum revisi

Pada permasalahan nomor satu tersebut, validator meminta untuk merevisi bidang singgung karena bidang tersbut berada pada dua dimensi. Sedangkan bola termasuk banung ruang (tiga dimensi). Sehingga peneliti merevisi dengan mengubah menjadi tiga koordinat yaitu titik $(2,10,0),(-2,14,0)$,dan $(6,6,0)$. Berikut hasil revisi sesuai saran dari validator.

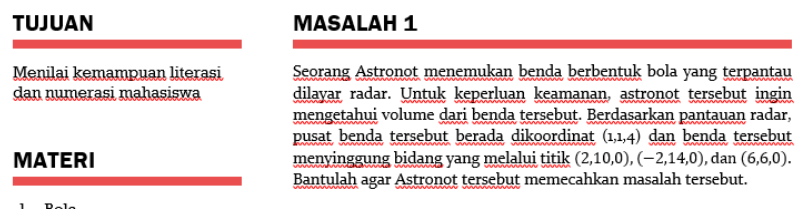

Gambar 2. Permasalahan setelah revisi sesuai saran validator

Kepraktisan Produk Asesmen Berorientasi Kontekstual

Sebanyak 35 mahasiswa memberikan respon positif pada produk asesmen yang dikembangkan oleh peneliti. Respon positif diperoleh dari persentase aspek kemudahan penggunaan memperoleh skor 78,5\% dan aspek kebahasaan memperoleh $97,8 \%$. Sehingga secara keseluruhan produk asesmen berada pada ketegori praktis.

Keefektivan Produk Asesmen Berorientasi Kontekstual

Keefektivan asesmen berorientasi kontekstual yang sudah dikembangkan ini dilihat dari adanya peningkatan kemampuan literasi dan numerasi matematika mahasiswa. Peningkatan kemampuan literasi dan numerasi matematika mahasiswa dilihat dari apakah hasil pekerjaan mahasiswa terhadap soal tes tersebut dapat menunjukkan indikator-indikator literasi dan numerasi matematika. Indikator literasi matematika antara lain: 1) mahasiswa dapat merumuskan masalah nyata, 2) mahasiswa dapat menggunakan matematika, 3) mahasiswa dapat menafsirkan solusi, dan 4) mahasiswa mengevaluasi solusi. Sedangkan, indikator numerasi matematika antara lain: 1) mahasiswa mampu menggunakan berbagai macam angka atau simbol yang terkait dengan matematika dasar dalam menyelesaikan masalah kehidupan sehari-hari, 2) mahasiswa mampu menganalisis informasi yang ditampilkan dalam bentuk grafik, tabel, bagan, diagram, atau yang lain, 3) mahasiswa mampu menafsirkan hasil analisis tersebut untuk memprediksi dan mengambil keputusan.

Peningkatan kemampuan literasi dan numerasi matematika diperoleh dari hasil pretest dan hasil tes asesmen berorientasi kontekstual. Berikut tabel peningkatan kemampuan literasi dan numerasi matematika mahasiswa.

\begin{tabular}{|c|c|c|}
\hline Indikator & $\begin{array}{l}\text { Persen } \\
\text { Keterc }\end{array}$ & $\begin{array}{l}\text { ase } \\
\text { paian }\end{array}$ \\
\hline $\begin{array}{l}\text { Kemampuan } \\
\text { literasi }\end{array}$ & $\begin{array}{l}\text { Pre- } \\
\text { tes }\end{array}$ & $\begin{array}{l}\text { Tes } \\
\text { Berorientasi } \\
\text { Kontekstual }\end{array}$ \\
\hline $\begin{array}{l}\text { 1. mahasiswa dapat } \\
\text { merumuskan } \\
\text { masalah nyata }\end{array}$ & $62,5 \%$ & $83,3 \%$ \\
\hline $\begin{array}{l}\text { 2. mahasiswa dapat } \\
\text { menggunakan } \\
\text { matematika }\end{array}$ & $56,3 \%$ & $79,2 \%$ \\
\hline $\begin{array}{l}\text { 3. mahasiswa dapat } \\
\text { menafsirkan } \\
\text { solusi }\end{array}$ & $47,9 \%$ & $75 \%$ \\
\hline $\begin{array}{l}\text { 4. mahasiswa } \\
\text { mengevaluasi } \\
\text { solusi }\end{array}$ & $43,8 \%$ & $75 \%$ \\
\hline $\begin{array}{l}\text { Kemampuan } \\
\text { Numerasi }\end{array}$ & & \\
\hline $\begin{array}{l}\text { 1. mahasiswa } \\
\text { mampu } \\
\text { menggunakan } \\
\text { berbagai angka } \\
\text { atau simbol } \\
\text { berkaitan dengan } \\
\text { matematika } \\
\text { dasar }\end{array}$ & $60,4 \%$ & $81,6 \%$ \\
\hline
\end{tabular}


Terakreditasi Peringkat 4 (No. SK: 36/E/KPT/2019)

\begin{tabular}{|c|c|c|c|}
\hline 2. & $\begin{array}{l}\text { mahasiswa } \\
\text { mampu } \\
\text { menganalisis } \\
\text { informasi yang } \\
\text { ditampilkan } \\
\text { dalam bentuk } \\
\text { lain (grafik, } \\
\text { tabel, bagan, } \\
\text { diagram, atau } \\
\text { dll) }\end{array}$ & $66,7 \%$ & $72,9 \%$ \\
\hline 3. & $\begin{array}{l}\text { mahasiswa } \\
\text { mampu } \\
\text { menafsirkan } \\
\text { hasil analisis } \\
\text { tersebut untuk } \\
\text { memprediksi dan } \\
\text { mengambil } \\
\text { keputusan }\end{array}$ & $64,6 \%$ & $79,2 \%$ \\
\hline
\end{tabular}

Pada rincian tabel di atas, terlihat bahwa mahasiswa mengalami peningkatan persentase ketercapaian di semua indikator kemampuan literasi maupun numerasi matematika. Hal tersebut menunjukkan bahwa penggunaan asesmen berorientasi kontekstual dapat dikatakan efektif dalam meningkatkan kemampuan literasi dan numerasi matematika mahasiswa. Berikut ditampilkan contoh pekerjaan mahasiswa dalam menyelesaikan asesmen berorientasi kontekstual.
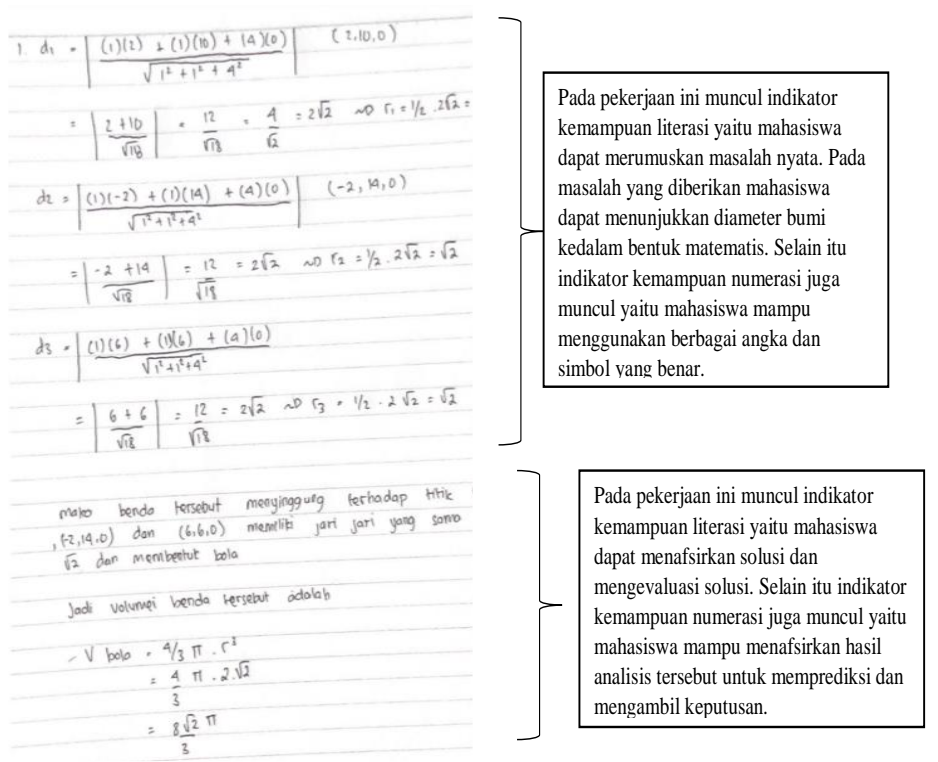

Berdasarkan hasil di atas, kemampuan literasi maupun numerasi matematika dapat didukung dengan menerapkan prinsip kontekstual pada asesmen yang diberikan. Hal tersebut sejalan dengan penelitian yang dilakukan oleh (Wahyuningtyas et al., 2020) yang mengatakan bahwa pendekatan kontekstual efektif dalam mendukung kemampuan literasi matematis. Selain itu, penelitian oleh (Pangesti, 2018) juga menjelaskan bahwa permasalahan kontekstual matematika berkaitan erat dengan kemampuan literasi maupun numerasi.

Reliabel Asesmen Berbasis Kontekstual

Analisis reliabilitas dilakukan untuk menentukan konsistensi butir tes dalam meningkatkan kemampuan literasi dan numerasi matematika mahasiswa. Uji reliabilitas menggunakan bantuan software SPSS dan memperoleh nilai koefisien reliabilitas Alpha Cronbach $r=0,79$. Hal tersebut menunjukkan bahwa butir tes pada asesmen berorientasi kontekstual dapat dikatakan reliabel. Hal ini sependapat dengan penelitian yang mengatakan bahwa butir tes dikatakan reliabel jika nilai koefisien yang diperoleh lebih dari 0,7 (Setemen, 2018).

\section{KESIMPULAN}

Pengembangan asesmen berorientasi kontekstual untuk meningkatkan kemampuan literasi matematika dan numerasi mahasiswa melalui tiga tahapan antara lain tahap identifikasi dan kajian permasalahan, tahap pengembangan, dan tahap penilaian. Asesmen yang dikembangkan adalah instrumen tes. Hasil pengembangan menunjukkan asesmen tes berkategori valid, praktis, efektif, dan reliabel.

\section{SARAN}

Penelitian ini memiliki keterbatasan pada pengembangan asesmen tes. Penelitian selanjutnya dapat dikembangkan kembali kepada jenis-jenis asesmen yang lain dengan materi yang dapat dikembangkan pula.

\section{DAFTAR PUSTAKA}

Annur, M. F. (2020). Analisis kesulitan mahasiswa pendidikan matematika. Jurnal Kajian, Pnelitian Dan Pengembangan Kependidikan, 6356.

Anugraheni, I. (2020). Analisis Kesulitan Mahasiswa dalam Menumbuhkan Berpikir Kritis Melalui Pemecahan Masalah. Jurnal Cendekia: Jurnal Pendidikan Matematika, 4(1). https://doi.org/10.31004/cendekia.v4i1. 
Terakreditasi Peringkat 4 (No. SK: 36/E/KPT/2019)

197

Ayuningtyas, N., \& Sukriyah, D. (2020). Analisis pengetahuan numerasi mahasiswa matematika calon guru. Matematika Dan Pendidikan Matematika, 9(02), 237-247. http://ejournal.unkhair.ac.id/index.php/ deltapi/article/view/2299

Dirgantoro, K. P. S. (2019). Analisis Kesulitan Mahasiswa PGSD pada Mata Kuliah Geometri. JNPM (Jurnal Nasional Pendidikan Matematika), 3(1). https://doi.org/10.33603/jnpm.v3i1.100 8

Hartatik, S. (2020). Indonesia Kemampuan Numerasi Mahasiswa Pendidikan Profesi Guru Sekolah Dasar dalam Menyelesaikan Masalah Matematika. Education and Human Development Journal, 5(1), 32-42. https://doi.org/10.33086/ehdj.v5i1.1456

Hera, R., \& Sari, N. (2015). Literasi Matematika: Apa, Mengapa dan Bagaimana? SEMINAR NASIONAL MATEMATIKA DAN PENDIDIKAN MATEMATIKA UNY 2015713.

Hidayat, N. Y., Wardono, \& Rusilowati, A. (2019). Analisis Kemampuan Literasi Matematika Ditinjau Dari Metakognisi Siswa dalam Pembelajaran Synectics Berbantuan Schoology. Prisma, Prosicing Seminar Nasional Matematika, 2.

Karim, I., Mariani, A., \& Tohopi, M. R. (2019). Aplikasi Pembelajaran Matematika Kelas III SD Berbasis Android. Jurnal Teknologi Informasi Indonesia (JTII), l(1).

https://doi.org/10.30869/jtii.v1i1.298

Mahmud, M. R., \& Pratiwi, I. M. (2019). LITERASI NUMERASI SISWA DALAM PEMECAHAN MASALAH TIDAK TERSTRUKTUR. KALAMATIKA Jurnal Pendidikan Matematika, $\quad$ 4(1). https://doi.org/10.22236/kalamatika.vol 4no1.2019pp69-88

Mardhiyana, D., \& Jailani, J. (2017). Pengembangan model asesmen pembelajaran matematika SMA berdasarkan kurikulum 2013. Pythagoras: Jurnal Pendidikan Matematika, 12(2), 135-148. https://doi.org/10.21831/pg.v12i2.1758 6

Mujib, M., Mardiyah, M., \& Suherman, S. (2020). STEM : Pengaruhnya terhadap Literasi Matematis dan Kecerdasan Multiple Intelligences. Indonesian Journal of Science and Mathematics Education, 3(1), 66-73. https://doi.org/10.24042/ijsme.v3i1.544 8

Musthofa, M. (2019). Authentic Assessment For Improving The Quality Of Learning. Idarah Tarbawiyah: Journal of Management in Islamic Education, l(1). https://doi.org/10.32832/itjmie.v1i1.27 03

Muta'ali, J. A. (2020). OPINI MASYARAKAT TENTANG ASESMEN NASIONAL SEBAGAI PENGANTI UJIAN NASIONAL. Journal of Chemical Information and Modeling, 53(9).

Oktaviyanthi, R., \& Agus, R. N. (2019). EKSPLORASI KEMAMPUAN PEMECAHAN MASALAH BERDASARKAN KATEGORI PROSES LITERASI MATEMATIS. Jurnal Pendidikan Matematika, 13(2). https://doi.org/10.22342/jpm.13.2.7066 .163-184

Pangesti, F. T. P. $\quad$ (2018). Menumbuhkembangkan Literasi Numerasi Pada Pembelajaran Matematika Dengan Soal Hots. Indonesian Digital Journal of Mathematics and Education, 5(9).

Prasetiyo, N. A., \& Perwiraningtyas, P. (2017). Pengembangan Buku Ajar Berbasis Lingkungan Hidup pada Mata Kuliah Biologi di Universitas Tribhuwana TunggaDewi. Jurnal Pendidikan Biologi Indonesia, 3(1), 19-27.

Setemen, K. (2018). PENGEMBANGAN DAN PENGUJIAN VALIDITAS BUTIR INSTRUMEN KECERDASAN LOGIS-MATEMATIS. Jurnal Pendidikan Teknologi Dan Kejuruan, 
15(2). https://doi.org/10.23887/jptkundiksha.v15i2.14197

Setiawan, \& Dores, O. J. B. (2019). MENINGKATKAN KEMAMPUAN LITERASI MATEMATIS MAHASISWA MELALUI BAHAN AJAR BERBASIS KETERAMPILAN METAKOGNISI. J-PiMat: Jurnal Pendidikan Matematika, 1(2), 91-99. https://doi.org/10.31932/jpimat.v1i2.511

Seto, S. B., \& Bantas, M. G. D. (2020). Pengaruh Motivasi Belajar dan Formasi Duduk Terhadap Hasil Belajar Mata Kuliah Asessmen Pembelajaran Matematika. Jurnal Cendekia: Jurnal Pendidikan Matematika, $4(2)$. https://doi.org/10.31004/cendekia.v4i2. 258

Sukmawati, R. (2018). Analisis Kemampuan Literasi Matematika Berdasarkan Kemampuan Awal Matematis Mahasiswa. Seminar Nasional Pendidikan Matematika Dahlan, 734743.

Wahyuningtyas, A., Nindiasari, H., \& Fatah, A. (2020). EFEKTIVITAS PENDEKATAN KONTEKSTUAL BERBASIS KARAKTER DAN BUDAYA LOKAL TERHADAP KEMAMPUAN LITERASI MATEMATIS SISWA SMP. Jurnal Inovasi Dan Riset Pendiidkan Matematika, $X(1)$.

Yasin, M., \& Netriwati, N. (2019). Analisis Kesulitan Belajar: Dampak Latar Belakang Kejuruan ditinjau dari Proses Pembelajaran Matematika Perguruan Tinggi. Desimal: Jurnal Matematika, 2(1), 59-67. https://doi.org/10.24042/djm.v2i1.2040

Yudha, R. P. (2019). PENGEMBANGAN INSTRUMEN ASESMEN OTENTIK TES KETERAMPILAN BERPIKIR KRITIS PADA PEMBELAJARAN MATEMATIKA. $M A T H L I N E$ : Jurnal Matematika Dan Pendidikan Matematika, $4(1)$. https://doi.org/10.31943/mathline.v4i1. 101 